\title{
Rhubarb (Rheum emodi) Improves Some Immunity Markers and Blood Glucose in Rats Exposed to Glucocorticoids.
}

\author{
Rasha M. Bahnasy \\ Nutrition and Food Science Dept. Faculty of Home Economics, Al- Azhar \\ University
}

\section{ABSTRACT}

Rhubarb (Rheum emodi) commonly known as Rhubarb belongs to family Polygonaceae. Traditionally plant is widely used as tonic, diuretic, laxative, and to treat ulcers, diarrhea, fever, cough and indigestion. The main target of this study is to investigate the possible protective effect of rhubarb as phytoestrogens source on some Immunity markers and blood glucose in exposed rats to corticosteroids. The alleviating roles of this plant on some other side effects of glucocorticoid therapy were also studied. Fifty albino rats (Sprague Dawley strain) weighing $150 \pm 10 \mathrm{~g}$ were used and were divided randomly into five equal groups. The first group was fed on basal diet as a negative control, while other groups were fed on basal diets containing $100 \mathrm{mg}$ of prednisone as a glucocorticoid/ $\mathrm{kg}$ diet (GCD). The positive control group was kept feeding on GCD alone, while others were fed on GCD containing 10, 20 , and $30 \mathrm{~g}$. of rhubarb powder $/ \mathrm{kg}$ diet. The experiment lasted for 8 weeks. Feed intake, body weight gain and feed efficiency ratio were finally calculated. Besides, the complete blood count (CBC), IGg, IGm as Immunity markers, blood glucose was also determined. Results indicated that feeding GCD resulted in a significant decline in CBC. Feed intake, body weight gains and hence feed efficiency ratio were also reduced significantly. Conversely, blood glucose increased significantly. Supplementation of GCD with rhubarb alleviated the marked lesion noticed in the complete blood count (CBC) and Immunity markers. Blood glucose was decreased. Feed intake, body weight gains and hence feed efficiency ratio were improved in rhubarb -fed groups. Finally, dietary supplementation with rhubarb powder is recommended to prevent glucocorticoid side effects. The supplementation was more potent in elevating Immunity markers .

Keywords: Rhubarb, glucocorticoid, immunity markers, blood glucose 


\section{Introduction}

Glucocorticoids are commonly used in the cure of patients with long-lasting noninfectious inflammatory diseases, particularly asthma, chronic lung illness, rheumatoid arthritis, further connective tissue diseases, and inflammatory intestines disease, and in organ transplantation. Although, They are quick, and causing bone loss in vertebral fractures is the most incapacitating impact(Lane \& Lukert, 1998).

Phytoestrogens are fluctuated gathering of plant-inferred aggravates that basically or practically mirror mammalian estrogens and show potential advantages for human wellbeing(Jones et al., 2003).

As of now, four distinct groups of phenolic mixes delivered by plants are considered phytoestrogens: the isoflavonoids, stilbenes, lignans, and coumestans. Various classes of phytoestrogens and assorted mixes inside each class influence the estrogen-interceded reaction in various ways(Cornwell $\boldsymbol{e t}$ al., 2004).

Rhubarb Rheum emodi is a type of plant in the family Polygonaceae. In the thousand years prior to China Rhubarb pull has been utilized for therapeutic purposes, which is thought to have been ordered around 2,700 years' back (Wani et al., 2012).It has been customarily used to treat neurotic sicknesses like fevers, ulcers, bacterial contamination, and contagious diseases furthermore used to treat kidney stones, jaundice (Babu et al., 2003).Various Assortments have been tamed for human utilization, the majority of which are perceived as Rheum x hybridum by the Royal Horticultural Society. Rhubarb contains anthraquinones including rhein, and emodin and their glycosides, which give cathartic and purgative properties. It is also useful as a cathartic in case of constipation, it contains tannins, flavonoids, and stilbene. Rhubarb is useful in the treatment of diseases like cancer, microbial, inflammation, and fungal infections, liver, diabetes, and kidney disease(Sanghi \& Tiwle, 2016). From the past information our hypothesis is Phytoestrogens prevent the side effects of glucocorticoid. Thus, in this study, we are trying to assess the job of Rhubarb as sources of Phytoestrogens in preventing glucocorticoid effects on immunity system and other related parameters. 


\section{Materials and Methods}

Fifty normal male albino rats of Sprague Dawley strain (8 weeks old) weighing $150 \pm 10 \mathrm{~g}$ were obtained from the laboratory animal colony Ministry of Health and Population, Helwan, Egypt. Rhubarb was obtained from the Agriculture Seeds, Herbs and Medicinal Plants Company, Cairo, Egypt. Prednisone acetate, casein, and cellulose powder were obtained from El-Sharqiya co., while vitamin and salt mixture was from Adwiya co., Kafr El-Zayat, Egypt. Corn oil and corn starch were purchased from the local market, Tanta City, Gharbia, Governorate, Egypt.

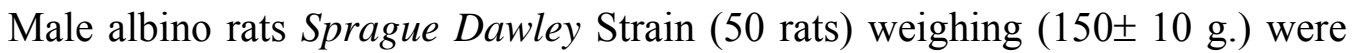
housed in well-aerated cages under a hygienic condition and they were fed on the basal diet for one week for adaptation ad libitum in the animal house for Faculty of Home Economics, Al-Azhar University.

Diets were presented to rats in special non - scattering feeding cups to avoid loss of food and contamination. Tape water was also provided adlibtum and checked daily.

The basal diet was composed of $14 \%$ casein ( $>85 \%$ protein), $4 \mathrm{~g}$ con oil ( $4 \%$ fat) , 3.5g minerals ( $3.5 \%$ minerals) , $1 \mathrm{~g}$ vitamins mixture ( $1 \%$ vitamins), $5 \mathrm{~g}$ cellulose ( $5 \%$ fiber ), choline chloride 0.25 and corn starch up to $100 \mathrm{~g}$ according to(Reeves et al., 1993), The salt mixture which was used in this experiment according to (Hegsted et al., 1941), and the vitamin mixture is stated according to (Horwitz, 1975).

After this week rats were divided into5 Groups (10 rats each) as following, the first group was fed on basal diet as a negative control, while other groups were fed on basal diets containing $100 \mathrm{mg}$ of prednisone as a glucocorticoid/ $\mathrm{kg}$ diet (GCD) to establish osteoporotic model according to the method described by (Liao et al., 2003). The positive control group was kept feeding on glucocorticoid diet (GCD) alone, while others were fed on GCD containing 10, 20 , and $30 \mathrm{~g}$. of rhubarb powder $/ \mathrm{kg}$ diet.

The experiment period lasted for (8weeks) during which the quantities of diet, which were consumed and/or wasted, they were recorded every day. The rat's weight was also recorded weekly. At the end of the experiment, rats were fasted overnight and anesthetized with diethyl ether. Blood samples were withdrawn from eye plexus of veins into heparinized capillary tubes to test blood picture. After sacrificing rats, other blood samples were collected in clean dry centrifuge tubes from the hepatic portal vein and left for 10 minutes to clot at room temperature, then centrifuged for 15 minutes at $3000 \mathrm{rpm}$ to separate the 
serum. The serum was carefully separated and it was transferred in to dry clean Eppendorf tubes and it was kept frozen at $-20^{\circ} \mathrm{C}$ until analysis.

The liver, kidney, heart and spleen were removed from each rat by careful dissection, they were cleaned from the adhesive matter by a saline solution $(0.9 \%)$, they were dried by filter paper and they were weighted to calculate organs weight/body weight $\%$.At the end of the experiment feed intake, body weight gains and organs weight as a percent of total body weight were determined .It is firmed according to (Chapman et al., 1959).

\section{Biochemical Analysis:}

Blood picture or complete blood count (CBC) tests including the determination of red blood cell count (R.B.Cs), mean corpuscular volume (M.C.V.), mean corpuscular hemoglobin (M.C.H.) , mean corpuscular hemoglobin concentration (M.C.H.C.), and packed cell volume or hematocrit (HCT) was determined according to (Dacie \& Lewis, 1984). While Hemoglobin ( $\mathrm{Hb}$ ) concentration was determined according to (Butnaru et al., 2002). WBCs count was determined according to (Dacie \& Lewis, 1984). The leukocyte differential count including the determination of Eosinophils, Monocytes, Lymphocytes and Neutrophils were determined according to (Houwen, 2001).Platelets were determined according to(Crews et al., 1983). Total immunoglobulin (IgG and IgM) was determined by Radioimmunoassay as described by the method of (Patrono \& Peskar, 1987).

Serum glucose was determined according to (Syiem et al., 2002).

Statistical Analysis of data:

Statistical analyses were performed by using a computer program statistical package for social science (SPSS), using Duncan Multiple Range test (one-way ANOVA test) according to(Armitage et al., 1987), The results were expressed as mean $\pm \mathrm{SD}$.

\section{Results}

\section{Effect of Rhubarb on dietary parameters in rats fed with glucocorticoid diet (GCD)}

As shown in the table (1). It could be noticed that, the feed intake of the (+ve) control group $(\mathrm{P}<0.05)$ decreased significantly compared with the $(-\mathrm{ve})$ control group. In respect to rats which fed on GC -containing diets supplemented with $1 \%$ Rhubarb showed that there is no significant decrease $(p<0.05)$ in feed 
intake comparing with the $(-\mathrm{ve})$ control group. All other treated groups $(\mathrm{P}<$ $0.05)$ decreased significantly in FI compared with the (- ve) control group.

Concerning the $(+\mathrm{ve})$ control group, it $(\mathrm{P}<0.05)$ decreased significantly in $\mathrm{BWG} \%$ comparing with the (-ve) control group. No significant differences $(\mathrm{P}<0.05)$ in $\mathrm{BWG} \%$ occurred among the $(+\mathrm{ve})$ control group and all other groups except the group which fed on 3\% rhubarb. It had recorded a significant increase comparing with the $(+v e)$ control group.

Concerning FER, the $(+\mathrm{ve})$ control group $(\mathrm{P}<0.05)$ decreased significantly comparing with the $(-\mathrm{ve})$ control group. Non-significant differences $(\mathrm{P}<0.05)$ occurred in FER among the(-ve) control group and all treated groups.

At the final, it could be observed that the best result of feed intake regarding treated groups was recorded by group received GCD supplemented with $1 \%$ Rhubarb. On the other hand, the best result for BWG \% regarding treated groups was for the treated group with 3\% Rhubarb. Arithmetically, the best result for FER regarding treated groups was for the group treated with $2 \%$ Rhubarb.

\section{Table (1): Effect of Rhubarb on dietary parameters in rats fed with glucocorticoid diet}

\begin{tabular}{|l|c|c|c|}
\hline \multirow{2}{*}{ Groups } & \multicolumn{3}{|c|}{ Parameters } \\
\cline { 2 - 4 } & FI (g/d/rat) & BWG \% & FER \\
\hline (-ve) Control & $8.58 \pm 0.98^{\mathrm{a}}$ & $56.09 \pm 4.27^{\mathrm{a}}$ & $0.154 \pm 0.033^{\mathrm{a}}$ \\
\hline (+ve) Control & $6.98 \pm 0.53^{\mathrm{b}}$ & $48.38 \pm 7.93^{\mathrm{c}}$ & $0.122 \pm 0.022^{\mathrm{b}}$ \\
\hline $1 \%$ Rhubarb & $7.07 \pm 0.38^{\mathrm{ab}}$ & $50.38 \pm 1.87^{\mathrm{abc}}$ & $0.126 \pm 0.005^{\mathrm{ab}}$ \\
\hline $2 \%$ Rhubarb & $6.65 \pm 1.16^{\mathrm{b}}$ & $54.72 \pm 8.62^{\mathrm{abc}}$ & $0.149 \pm 0.046^{\mathrm{ab}}$ \\
\hline $3 \%$ Rhubarb & $6.81 \pm 0.59^{\mathrm{b}}$ & $55.59 \pm 5.03^{\mathrm{ab}}$ & $0.141 \pm 0.016^{\mathrm{ab}}$ \\
\hline
\end{tabular}

Different superscript letters in the column denote significant differences $(\mathrm{P}<0.05)$.

\section{Effect of Rhubarb on relative organ weight in rats fed with glucocorticoid diet.}

As shown in the table (2). It can be noticed that, liver weight/body weight $\%$ of the $(+\mathrm{ve})$ control group $(\mathrm{P}<0.05)$ increased significantly than the $(-\mathrm{ve})$ control group. there is a significant difference $(\mathrm{P}<0.05)$ in liver weight/body weight $\%$ among the $(+\mathrm{ve})$ control group, and the groups which treated with $1 \& 2 \%$ Rhubarb. On the other hand, there are no significant difference $(\mathrm{P}<0.05)$ between the $(-\mathrm{ve})$ control group and the treated group with 3\% Rhubarb which recorded the best result.

Regarding the mean value of kidney weight/body weight $\%$, it can be noticed that the $(+\mathrm{ve})$ control group $(\mathrm{P}<0.05)$ increased significantly than the $(-\mathrm{ve})$ 
control group. All treated groups showed that there are non-significant differences $(\mathrm{P}<0.05)$ in kidney weight/body weight \% compared to the $(+\mathrm{ve})$ control group except the group which treated with $2 \%$ Rhubarb, it is recorded a significant decrease.

Concerning the mean value of heart weight/body weight $\%$, it can be noticed that the $(+\mathrm{ve})$ control group is significantly $(\mathrm{P}<0.05)$ increased as compared to the (-ve) control group. All treated groups showed that there are non-significant differences $(\mathrm{P}<0.05)$ in heart weight/body weight \% comparing with the $(+\mathrm{ve})$ control group except rats which were fed on GC -containing diet supplemented with $2 \%$ Rhubarb.

Regarding the mean value of spleen weight/body weight $\%$, it can be noticed that the $(+\mathrm{ve})$ control group is significantly $(\mathrm{P}<0.05)$ increased than the $(-\mathrm{ve})$ control group. All treated groups are significantly $(\mathrm{P}<0.05)$ increased in spleen weight/body weight $\%$ comparing with the (- ve) control group. The best result is recorded for rats which were fed on GCD supplemented with $2 \%$ Rhubarb.

\section{Table (2): Effect of Rhubarb on relative organs weight in rats fed with glucocorticoid diet}

\begin{tabular}{|c|c|c|c|c|}
\hline \multirow[b]{2}{*}{ Groups } & \multicolumn{4}{|c|}{ Parameters } \\
\hline & Liver\% & Kidney\% & Heart\% & Spleen \% \\
\hline (-ve) Control & $3.99 \pm 0.74^{\mathrm{c}}$ & $1.39 \pm 0.43^{c}$ & $0.97 \pm 0.39^{\mathrm{c}}$ & $0.99 \pm 0.43^{\mathrm{c}}$ \\
\hline (+ve) Control & $6.97 \pm 1.13^{\mathrm{a}}$ & $3.99 \pm 0.64^{\mathrm{a}}$ & $2.52 \pm 0.69^{\mathrm{a}}$ & $3.80 \pm 0.86^{\mathrm{a}}$ \\
\hline 1\% Rhubarb & $5.56 \pm 0.78^{\mathrm{ab}}$ & $3.51 \pm 0.77^{\mathrm{ab}}$ & $2.05 \pm 0.77^{\mathrm{ab}}$ & $3.17 \pm 0.78^{\mathrm{ab}}$ \\
\hline 2\% Rhubarb & $6.88 \pm 0.2^{\mathrm{a}}$ & $2.89 \pm 0.19^{b}$ & $1.29 \pm 0.11^{b}$ & $2.38 \pm 0.94^{b}$ \\
\hline 3\% Rhubarb & $5.12 \pm 0.99^{b c}$ & $3.94 \pm 0.85^{\mathrm{a}}$ & $2.49 \pm 0.60^{\mathrm{a}}$ & $3.61 \pm 0.76^{\mathrm{a}}$ \\
\hline
\end{tabular}

Different superscript letters in the column denote significant differences $(\mathbf{P}<\mathbf{0 . 0 5})$.

\section{Effect of Rhubarb on complete blood count (CBC) tests in rats fed with glucocorticoid diet.}

The findings of $\mathrm{CBC}$ for rats which treated with GCD supplemented with Rhubarb are recorded in the table (3). Statistically, it can be noticed that, the mean value of hemoglobin of the $(+v e)$ control group is significantly $(\mathrm{P}<0.05)$ decreased than the $(-\mathrm{ve})$ control group. The mean value of hemoglobin is significantly $(\mathrm{P}<0.05)$ increased in all groups treated with Rhubarb comparing with the $(+v e)$ control group. The best result is recorded for group of rats which treated with 3\% Rhubarb.

It can be noticed that the (+ve) control group is recorded a significant decrease $(\mathrm{P}<0.05)$ in all studied $\mathrm{CBC}$ parameters including HCT, R.B. Cs, 
M.C.V., M.C.H. and M.C.H.C. comparing with healthy control group. The mean value of HCT, R.B. Cs, M.C.V., M.C.H. and M.C.H.C were significantly $(\mathrm{P}<0.05)$ affected as a result of supplementation with rhubarb leaves, it is significantly improved $(\mathrm{P}<0.05)$ in all Rhubarb-treated groups comparing with untreated group. Anyway, it could not reach the normal value recorded by healthy can group. The best result of hematocrit is recorded for the group of rats which treated with $2 \%$ Rhubarb. While the best results for R.B.Cs, M.C.V., M.C.H. and M.C.H.C are recorded for the group of rats which treated with 3\% Rhubarb because these treatments showed non-significant changes in these parameters, as compared to the negative control group.

\section{Table (3): Effect of Rhubarb on complete blood count (CBC) tests in rats fed with glucocorticoid diet}

\begin{tabular}{|c|c|c|c|c|c|c|}
\hline \multirow{2}{*}{ Groups } & \multicolumn{6}{|c|}{ Parameters } \\
\cline { 2 - 7 } & $\begin{array}{c}\text { Hb } \\
(\mathrm{gm} / \mathrm{dL})\end{array}$ & $\begin{array}{c}\text { HCT } \\
(\%)\end{array}$ & $\begin{array}{c}\text { R.B.Cs } \\
\left(\times 10^{6} / \mathrm{ul}^{\prime}\right)\end{array}$ & $\begin{array}{c}\text { M.C.V. } \\
(\mathrm{fL})\end{array}$ & $\begin{array}{c}\text { M.C.H. } \\
(\mathrm{pg})\end{array}$ & $\begin{array}{c}\text { M.C.H.C. } \\
(\mathrm{gm} / \mathrm{dL})\end{array}$ \\
\hline$(-\mathrm{ve})$ Control & $15.87 \pm 0.59^{\mathrm{a}}$ & $1.29 \pm 0.53^{\mathrm{a}}$ & $7.98 \pm 0.22^{\mathrm{a}}$ & $65.8 \pm 0.09^{\mathrm{a}}$ & $21.4 \pm 0.45^{\mathrm{ab}}$ & $32.6 \pm 0.64^{\mathrm{ab}}$ \\
\hline$(+\mathrm{ve})$ Control & $14.37 \pm 0.36^{\mathrm{c}}$ & $0.52 \pm 0.21^{\mathrm{d}}$ & $6.17 \pm 0.22^{\mathrm{c}}$ & $58.03 \pm 0.23^{\mathrm{c}}$ & $18.87 \pm 0.94^{\mathrm{c}}$ & $31.33 \pm 0.73$ \\
\hline $1 \%$ Rhubarb & $14.9 \pm 0.24^{\mathrm{b}}$ & $\mathbf{0 . 8 0} \pm 0.33^{\mathrm{c}}$ & $7.41 \pm 0.67^{\mathrm{b}}$ & $59.97 \pm 2.18^{\mathrm{c}}$ & $19.07 \pm 0.05^{\mathrm{b}}$ & $32.07 \pm 0.52^{\mathrm{b}}$ \\
\hline $2 \%$ Rhubarb & $15.37 \pm 0.19^{\mathrm{b}}$ & $1.15 \pm 0.47^{\mathrm{b}}$ & $7.63 \pm 0.34^{\mathrm{ab}}$ & $62.6 \pm 3.13^{\mathrm{b}}$ & $20.67 \pm 0.67^{\mathrm{a}}$ & $33.1 \pm 0.59^{\mathrm{a}}$ \\
\hline $3 \%$ Rhubarb & $16.07 \pm 0.55^{\mathrm{a}}$ & $\mathbf{0 . 8 3} \pm 0.34^{\mathrm{b}}$ & $7.67 \pm 0.33^{\mathrm{ab}}$ & $64.83 \pm 0.36^{\mathrm{a}}$ & $20.77 \pm 0.23^{\mathrm{a}}$ & $32.93 \pm 0.1^{\mathrm{a}}$ \\
\hline
\end{tabular}

Different superscript letters in the column denote significant differences $(\mathrm{P}<0.05)$.

\section{Effect of Rhubarb on white blood cells differential count and platelets in rats fed with glucocorticoid diet}

The findings of white blood cells, differential count and platelets for rats which treated with GCD supplemented with Rhubarb are recorded in the table (4). Statistically, it can be noticed that, the mean value of white blood cells (WBC) for the $(+\mathrm{ve})$ control group significantly $(\mathrm{P}<0.05)$ decreased comparing with the $(-\mathrm{ve})$ control group. There is non-significant $(\mathrm{P}<0.05)$ difference in the mean value of WBC in all treated groups comparing with the (+ve) control group. The best result is recorded for group of rats which treated with 1\% Rhubarb.

It can be noticed that the $(+\mathrm{ve})$ control group is recorded a significant $(\mathrm{P}<0.05)$ decrease in all studied differential count parameters including neutrophils, lymphocytes, monocytes, eosinophils and platelets comparing with healthy 
control group. The mean value of neutrophils, and platelets are significantly $(\mathrm{P}<0.05)$ affected as a result of supplementation with rhubarb leaves, it is improved significantly $(\mathrm{P}<0.05)$ in all rhubarb-treated groups comparing with untreated group. However, it could not reach the normal value recorded by healthy control group except group of rats treated with 3\% rhubarb. It is recorded non- significant $(\mathrm{P}<0.05)$ difference in the mean value of neutrophils.

On the other hand, all treated groups are recorded non-significant $(\mathrm{P}<0.05)$ differences in the mean value of lymphocytes, monocytes, and eosinophils comparing with the $(+\mathrm{ve})$ control group. The best results of WBC and platelets are recorded for the group of rats which treated with $1 \%$ rhubarb.

\section{Table (4): Effect of Rhubarb on white blood cells differential count and platelets in rats fed with glucocorticoid diet}

\begin{tabular}{|c|c|c|c|c|c|c|}
\hline \multirow[b]{2}{*}{ Groups } & \multicolumn{6}{|c|}{ Parameters } \\
\hline & $\begin{array}{c}\text { WBC } \\
\left(\times 10^{3} / \mathbf{u L}\right)\end{array}$ & $\begin{array}{c}\text { neutrophils } \\
\left(\times 10^{3} / \mathrm{uL}\right)\end{array}$ & $\begin{array}{c}\text { Lymphocytes } \\
\left(\times 10^{3} / \mathrm{uL}\right)\end{array}$ & $\begin{array}{c}\text { Monocytes } \\
\left(\times 10^{3} / \mathrm{uL}\right)\end{array}$ & $\begin{array}{c}\text { Eosinophils } \\
\left(\times 10^{3} / \mathrm{uL}\right)\end{array}$ & $\begin{array}{l}\text { platelets } \\
\left(\times 10^{3} / \mathrm{uL}\right)\end{array}$ \\
\hline (-ve) Control & $1.52 \pm 0.1^{a}$ & $0.21 \pm 0.03^{a}$ & $1.23 \pm 0.09^{\mathrm{a}}$ & $0.11 \pm 0.019^{b}$ & $0.08 \pm 0.03^{a}$ & $585 \pm 55.01^{\mathrm{c}}$ \\
\hline (+ve) Control & $0.86 \pm 0.26^{b}$ & $0.103 \pm 0.041$ & $0.57 \pm 0.21^{b c}$ & $0.04 \pm 0.005^{b}$ & $0.02 \pm 0.002^{b}$ & $341 \pm 11.2^{d}$ \\
\hline 1\% Rhubarb & $0.97 \pm 0.37^{b}$ & $0.15 \pm 0.02^{b}$ & $0.68 \pm 0.42^{b c}$ & $0.04 \pm 0.008^{b}$ & $0.07 \pm 0.03^{b}$ & $941.7 \pm 150.7^{a}$ \\
\hline 2\% Rhubarb & $0.96 \pm 0.56^{b}$ & $0.15 \pm 0.04^{b}$ & $0.82 \pm 0.29^{b}$ & $0.08 \pm 0.001^{a b}$ & $0.04 \pm 0.005^{b}$ & $829.7 \pm 58.2^{b}$ \\
\hline 3\% Rhubarb & $0.63 \pm 0.09^{b}$ & $0.11 \pm 0.01^{b c}$ & $0.43 \pm 0.07^{c}$ & $0.05 \pm 0.003^{b}$ & $0.05 \pm 0.022^{b}$ & $859.7 \pm 94.4^{\text {ab }}$ \\
\hline
\end{tabular}

Different superscript letters in the column denote significant differences $(\mathrm{P}<0.05)$.

\section{Effect of Rhubarb on immunoglobulins in rats fed with glucocorticoid diet}

As shown in the table (5). It can be noticed that, serum immunoglobulins (IgG and $\operatorname{IgM})$ of the $(+\mathrm{ve})$ control group is significantly $(\mathrm{P}<0.05)$ increased compared to the (-ve) control group. Serum immunoglobulins (IgG and IgM) in all groups which treated with rhubarb significantly $(\mathrm{P}<0.05)$ decreased compared to the (+ve) control group. The best results are recorded for rats which were fed on GCD supplemented with $3 \%$ rhubarb, which were the nearest values to the (-ve) control group. Three percent rhubarb is more efficient than $1 \%$ Rhubarb and $2 \%$ Rhubarb in restoring the interrupted immunoglobulin levels.

The serum glucose level of the $(+\mathrm{ve})$ control group is significantly $(\mathrm{P}<0.05)$ increased comparing with the (-ve) control group as a result of treating rats with 
GC. Treating rats with $2 \& 3 \%$ Rhubarb resulted in significant $(\mathrm{P}<0.05)$ decrease in S. Glucose levels comparing with the (+ve) control group. On the other hand, the $\mathrm{S}$. Glucose level is not significantly $(\mathrm{P}<0.05)$ decreased comparing with the (+ve) control group as a result of feeding rats on $1 \%$ Rhubarb. The best results are recorded for rats which were fed on GCD supplemented with 3\% Rhubarb, the nearest values to the (-ve) control group. $2 \& 3 \%$ Rhubarb are more efficient than 1\% Rhubarb in restoring the $\mathrm{S}$. Glucose levels.

\section{Table (5): Effect of Rhubarb on immunoglobulins and serum glucose in rats fed with glucocorticoid diet}

\begin{tabular}{||c|r|r|c|}
\hline \multirow{2}{*}{ Groups } & \multicolumn{3}{|c|}{ Parameters } \\
\cline { 2 - 4 } & IgG (mg/dL) & IgM (mg/dL) & Serum glucose (mg/dL) \\
\hline (-ve) Control & $612 \pm 14.2^{\mathrm{e}}$ & $57.1 \pm 4.3^{\mathrm{e}}$ & $16.17 \pm 7.44^{\mathrm{c}}$ \\
\hline (+ve) Control & $1315 \pm 115^{\mathrm{a}}$ & $196.5 \pm 6.02^{\mathrm{a}}$ & $52.33 \pm 15.04^{\mathrm{a}}$ \\
\hline 1\% Rhubarb & $1211 \pm 9.92^{\mathrm{b}}$ & $157.6 \pm 17^{\mathrm{b}}$ & $43.5 \pm 6.35^{\mathrm{a}}$ \\
\hline 2\% Rhubarb & $1057.5 \pm 61.9^{\mathrm{c}}$ & $132.18 \pm 35.2^{\mathrm{c}}$ & $32.33 \pm 5.32^{\mathrm{b}}$ \\
\hline 3\% Rhubarb & $771.5 \pm 43.3^{\mathrm{d}}$ & $83.09 \pm 2.21^{\mathrm{d}}$ & $18 \pm 7.01^{\mathrm{c}}$ \\
\hline
\end{tabular}

Different superscript letters in the column denote significant differences $(\mathrm{P}<0$. $05)$.

\section{DISCUSSION}

The main purpose of this study is to assess the job of rhubarb as sources of phytoestrogens in preventing glucocorticoid effects on immunity system and other related parameters. The findings of the present study indicate that feeding rats on a diet contain GC, results in a significant decrease in feed intake (FI), body weight gain (BWG) and hence feed efficiency ratio (FER) comparing with healthy control group which was fed on basal diet. This is in agreement with(Liu et al., 2011)who found that GC treatment decreased appetite and body weight of the rodents. It was demonstrated that glucocorticoids, particularly at high dosages, incited obvious glucolipid metabolic aggravations and hyperinsulinemia, while it is down-regulated mRNA expression levels of the orexigenic neuropeptides, namely neuropeptide Y (NPY) and agouti-related protein (AGRP), and anorexigenic neuropeptide known as cocaine and amphetamine-regulated transcript (CART), in the hypothalamus of the rats. On the other hand GC treatment can increase body weight via fluid and sodium retention (Nesbitt, 1995). 
Although FI values are significantly increased, rhubarb -fed groups showed various degrees of weight loss. In this respect rhubarb contains loads of dietary fiber, minerals, vitamins, as well as polyphenolic antioxidants. The synergic action of all these nutrients improves body's metabolism rate and ensures elimination of unwanted fat. The stem and root of rhubarb contains anthraquinones-rhein and emodin. These ingredients have natural laxative and cathartic properties, making it a preferred vegetable for those who are on a strict low fat, low calorie diet.(Xing et al., 2011).

Banerjee \& Bonde, (2011)showed that when rat is fed on rhubarb in the diet caused low feed intake and body weight gain due to it have high percentage of dietary fiber (6.4-11.5\%) which has given the feeling of feeding up and it is one of the lowest caloric and increase the rate burns body fat.

Feeding rats on a diet contain GC, in the present study, resulted in a significant increase in relative organs weight, while feeding rats on a diet contain rhubarb resulted in a significant decrease in relative organs weight comparing with the (+ve) control group, these results were in agreement with(Al- Anazi et al., 2011)who revealed the significant job of phytoestrogen in treatment and keep up relative organs.

The complete blood count (CBC) with differential is one of the most common laboratory tests performed today. It gives information about the production of all blood cells and identifies the patient's oxygen-carrying capacity through the evaluation of red blood cell (RBC) indices, hemoglobin, and hematocrit. It also provides information about the immune system through the evaluation of the white blood cell (WBC) count with differential (George-Gay \& Parker, 2003). Feeding rats on a diet contain GC, in the present study, resulted in significant decrease in the mean value of Hb, HCT, R.B. Cs, M.C.V., M.C.H. and M.C.H.C. The major results of the present study are that rhubarb administration resulted in significant increase the mean value of Hb, HCT, R.B. Cs, M.C.V., M.C.H. and M.C.H.C, this improvement is may be due to decrease the serum content of lipid peroxidase and increase the superoxide dismutase activity in red blood cells (RBC) by the rhubarb roots (Shekha, 2008).

The major phytoconstituents reported to have been isolated from the rhizomes of rhubarb are free anthraquinones and their glycosides. The anthraquinones, both with and without carboxyl groups are found in Rheum emodi Linn. Anthraquinones with carboxyl group including rhein, while those without carboxyl group including chrysophanol, aloeemodin, emodin, physcion (emodinmonomethylether), chrysophanein and emodin glycoside (Malik et al., 
2010). Some alkyl derivatives of anthraquinones, like 6-methyl rhein and 6methyl aloe-emodin have also been reported (Singh et al., 2005).

Rhubarb root extract has shown higher percentage concentrations of emodin and physcion than aloe emodin, chrysophanol and rutins as $15 \%, 4.2 \%, 0.46$ $\%, 1.6 \%$ and $0.9 \%$ (Kumar \& Spandana, 2013).

The most abundant stilbenoid piceatannol-4 -O- $\beta$-D-glucopyranoside (PICG) and its aglycon piceatannol (PICE) were isolated from R. emodi rhizome. it could be rapidly in vivo metabolized into PICE with outstanding antioxidant potency, especially in reducing power, preventing lipid peroxidation, and decreasing oxidative stress-induced cell damage.(Chai et al., 2012).That antioxidant activity of stilbenoid compounds might increase with the number of hydroxyl group. Moreover, the presence of 3 -hydroxyl group would significantly enhance antioxidant activity. It is consistent with the concept that antioxidant properties of stilbenoids are associated with their ability to form stable radicals, and 3 -hydroxyl group could stabilize the semi quinone radicalanion intermediate by resonance through the trans double bond(Fang et al., 2002). This might be further demonstrated by the fact that aromatic compounds with catechol structure appear to be important scavenger (Cotelle et al., 1992).

Phenolic compounds have an important role in stabilizing lipid oxidation and they are associated with the antioxidant activity. The mechanism of phenolic compounds for doing antioxidant belongs to their radical scavenging ability mediated by hydroxyl groups. This mechanism comes from their redox characteristics, through attenuating high-energy form of oxygen (singlet) and triplet oxygen, neutralizing and absorbing free radicals or decomposing peroxides(Banerjee \& Bonde, 2011).

Feeding rats on a diet contain GCD, in the present study, resulted in significant decrease in the mean value of WBC and all studied differential count parameters including neutrophils, lymphocytes, monocytes, eosinophils and platelets. While rhubarb administration resulted in increase the mean value of WBC and all studied differential count parameters.

Kounsar et al., (2011) studied the immune-enhancing activity from ethyl acetate rhizome extract of Rheum emodi on the cell lines and it found to have an immune-enhancing effect through the release of various cytokines. There is a dose-dependent increase in the release of NO (Nitric Oxide) and cytokines tumor necrosis factor alpha (TNF- $\alpha$ ), interleukin 12 (IL-12), and a decrease in 
interleukin-10 (IL-10) by RAW 264.7 in macrophages cell line in the presence of extract alone.

Seo et al., (2012)investigated the effects of anthraquinone derivatives isolated from rhubarb on platelet activity. Four an thraquinone derivatives isolated from rhubarb examined, chrysophanol-8-O-glucoside (CP- 8-O-glc). It was found to have the most potent inhibitory effect on collagen- and thrombin induced platelet aggregation. CP-8-O-glc-treated mice showed significantly prolonged bleeding times. Furthermore, CP-8-Oglc was found to have a significant inhibitory effect on rat platelet aggregation in vivo and on thromboxane A2 formation in vitro.

Although the bioactivity of flavonoids appears to be mediated through a variety of mechanisms, particular attention has been focused on their direct and indirect antioxidant potentials. The antioxidant properties are conferred on flavonoids by the phenolic hydroxyl groups attached to ring structures and act as free radical scavengers, reducing agents, and metal chelators (Borges Bubols et al., 2013).

Concerning to immune globulins (Manzer \& Littlefield, 1988) demonstrate that despite the known immunosuppressive effects of glucocorticoids, these hormones can stimulate IgG biosynthesis and secretion in human myeloma lymphoblasts in vitro. Hydrocortisone (HC) as well as its synthetic derivatives have been shown to strongly enhance interleukin-4 (IL-4) induced in vitro IgE synthesis. The glucocorticoids alone led to a strongly enhanced secretion of IgG 1, IgG2 and IgG3, but not IgG4 (Klebl et al., 1994).

The main antioxidant compounds of diet that contain rhubarb are vitamins $\mathrm{C}$ and E, phenolic compounds. So, different studies show that they have a protective antioxidant effect on immunity status, cancer and cardiovascular diseases while excess of rhubarb powder led to increase the immunity productions which causes after the consumption for a long time cancer, skin allergic and heart diseases (Mallillin et al., 2008).

Steroid-induced hyperglycemia is a frequent problem in clinical practice that can generate or prolong hospital admissions and lead to repeat emergency visits without an adequate solution. However, steroid-induced hyperglycemia remains an underestimated problem in terms of both diagnosis and treatment. Factors contributing to this situation include the variety of corticosteroid preparations regimen available and especially the lack of involvement by practitioners 
prescribing steroids and the absence of clinical studies and specific recommendations for diagnosis and treatment (Ullastre \& Pérez, 2011).

Oral administration of $75 \%$ rhubarb ethanolic extract $(250 \mathrm{mg} / \mathrm{kg}$ body weight) for 30 days, resulted in decrease in the activities of glucose-6-phosphatase, fructose-1, 6-disphosphatase, aldolase and an increase in the activity of phosphoglucoisomerase and hexokinase in tissues(Radhika et al., 2010).

Oral administration of Rheum emodi rhizome extract of $75 \%$ ethanolic extract to diabetic rat for 30 days restored all marker enzymes to near control level (Radhika et al., 2012). Rhubarb contains stilbenoid, which helps in reducing blood sugar level.(Sanghi \& Tiwle, 2016).

For phytochemical screening; tests for alkaloids, carotenoids, sterols and triterpenes, fatty acids, coumarins, flavonoids, anthraquinones, tannins and polyphenols, glycosides, anthocyanosides and anthracenosides, carbohydrates and saponins, respectively. (Gupta et al.,2015). Polyphenols include flavonoids; have antidiabetic (Castro-Vazquez et al., 2016).

\section{Conclusion}

According to the current findings, it can be concluded that dietary supplementation with Rhubarb is recommended to prevent glucocorticoid side effects. The supplementation was more potent in elevating immunity markers. Further studies are necessary to validate these findings in a bigger population. Our findings may provide a background to design new therapies for clinical intervention in glucocorticoid side effects. 


\section{References}

Al-Anazi, A. F., Qureshi, V. F., Javaid, K., \& Qureshi, S. (2011). Preventive effects of phytoestrogens against postmenopausal osteoporosis as compared to the available therapeutic choices: An overview. Journal of Natural Science, Biology, and Medicine, 2(2), 154.

Armitage, P., Berry, G., \& Matthews, J. N. S. (1987). Comparison of several groups. Statistical Methods in Medical Research, 186, 213.

Babu, K. S., Srinivas, P. V, Praveen, B., Kishore, K. H., Murty, U. S., \& Rao, J. M. (2003). Antimicrobial constituents from the rhizomes of Rheum emodi. Phytochemistry, 62(2), 203-207.

Banerjee, S. K., \& Bonde, C. G. (2011). Total phenolic content and antioxidant activity of extracts of Bridelia retusa Spreng Bark: Impact of dielectric constant and geographical location. Journal of Medicinal Plants Research, 5(5), 817822 .

Borges Bubols, G., da Rocha Vianna, D., Medina-Remon, A., von Poser, G., Maria Lamuela-Raventos, R., Lucia Eifler-Lima, V., \& Cristina Garcia, S. (2013). The antioxidant activity of coumarins and flavonoids. Mini Reviews in Medicinal Chemistry, 13(3), 318-334.

Butnaru, E., Mircea, C., Agoroaei, L., Ilicenco, D., \& Proca, M. (2002). Variation of carboxyhemoglobin and of thiocyanates in smokers. Revista Medico-Chirurgicala a Societatii de Medici Si Naturalisti Din Iasi, 106(4), 782-786.

Castro-Vazquez, L., Alañón, M. E., Rodríguez-Robledo, V., Pérez-Coello, M. S., Hermosín-Gutierrez, I., Díaz-Maroto, M. C., Jordán, J., Galindo, M. F., \& Arroyo-Jimenez, M. del M. (2016). Bioactive flavonoids, antioxidant behaviour, and cytoprotective effects of dried grapefruit peels (Citrus paradisi Macf.). Oxidative Medicine and Cellular Longevity, 2016.

Chai, Y. Y., Wang, F., Li, Y. L., Liu, K., \& Xu, H. (2012). Antioxidant activities of stilbenoids from Rheum emodi Wall. In Evidence-based Complementary and Alternative Medicine (Vol. 2012). https://doi.org/10.1155/2012/603678

Chapman, D. G., Castillo, R., \& Campbell, J. A. (1959). Evaluation of protein in foods: 1. A method for the determination of protein efficiency ratios. Canadian Journal of Biochemistry and Physiology, 37(5), 679-686.

Cornwell, T., Cohick, W., \& Raskin, I. (2004). Dietary phytoestrogens and health. Phytochemistry, 65(8), 995-1016. 
Cotelle, N., Bernier, J. L., Henichart, J. P., Catteau, J. P., Gaydou, E., \& Wallet, J. C. (1992). Scavenger and antioxidant properties of ten synthetic flavones. Free Radical Biology and Medicine, 13(3), 211-219.

Crews, H. R., Carter, I. I. J. H., \& Sena, T. (1983). Method of stabilizing platelets for determining multiple platelet parameters in reference control and calibrator compositions; diluents therefor; and combination stabilization procedures. Google Patents.

Dacie, J. V, \& Lewis, S. M. (1984). Practical Haematology. Churchill Livingstone. London, New York.

Fang, J., Lu, M., Chen, Z., Zhu, H., Li, Y., Yang, L., Wu, L., \& Liu, Z. (2002). Antioxidant effects of resveratrol and its analogues against the free-radicalinduced peroxidation of linoleic acid in micelles. Chemistry-A European Journal, 8(18), 4191-4198.

George-Gay, B., \& Parker, K. (2003). Understanding the complete blood count with differential. Journal of PeriAnesthesia Nursing, 18(2), 96-117.

Gupta, R. K., Gupta, P. K., Jha, R. N., \& Bajracharya, G. B. (2015). Pharmacognostical comparison and standardization of the wild and cultivated rhizomes of Rheum australe (Padamchal) of Nepal. Journal of Pharmacognosy and Phytochemistry, 3(6), 112-116.

Hegsted, D. M., Mills, R. C., Elvehjem, C. A., \& Hart, E. B. (1941). Choline in the nutrition of chicks. Journal of Biological Chemistry, 138, 459-466.

Horwitz, W. (1975). Official methods of analysis (Vol. 222). Association of Official Analytical Chemists Washington, DC.

Houwen, B. (2001). The differential cell count. Laboratory Hematology, 7, 89100 .

Jones, G., Dwyer, T., Hynes, K., Dalais, F. S., Parameswaran, V., \& Greenaway, T. M. (2003). A randomized controlled trial of phytoestrogen supplementation, growth and bone turnover in adolescent males. European Journal of Clinical Nutrition, 57(2), 324.

Klebl, F. H., Weber, G., Kalden, J. R., \& Nüsslein, H. G. (1994). In vitro and in vivo effect of glucocorticoids on IgE and IgG subclass secretion. Clinical \& Experimental Allergy, 24(11), 1022-1029.

Kounsar, F., Rather, M. A., Ganai, B. A., \& Zargar, M. A. (2011). Immunoenhancing effects of the herbal extract from Himalayan rhubarb Rheum emodi Wall. ex Meissn. Food Chemistry, 126(3), 967-971. 
Kumar, H., \& Spandana, M. (2013). Qualitative and quantitative study of anthraquinone derivatives in the root extract of Rheum australe of Nepal (syn. Rheum emodi) by HPLC. J Pharmacogn Phytochem, 2(4).

Lane, N. E., \& Lukert, B. (1998). The science and therapy of glucocorticoidinduced bone loss. Endocrinology and Metabolism Clinics of North America, 27(2), 465-483.

Liao, J. M., Li, Q. N., Wu, T., Hu, B., Huang, L. F., Li, Z. H., Zhao, W. D., Zhang, M. C., \& Zhong, S. Z. (2003). Effects of prednisone on bone mineral density and biomechanical characteristics of the femora and lumbar vertebras in rats. Di 1 Jun Yi Da Xue Xue Bao= Academic Journal of the First Medical College of PLA, 23(2), 97.

Liu, X.-Y., Shi, J.-H., Du, W.-H., Fan, Y.-P., Hu, X.-L., Zhang, C.-C., Xu, H.B., Miao, Y.-J., Zhou, H.-Y., \& Xiang, P. (2011). Glucocorticoids decrease body weight and food intake and inhibit appetite regulatory peptide expression in the hypothalamus of rats. Experimental and Therapeutic Medicine, 2(5), 977-984.

Malik, S., Sharma, N., Sharma, U. K., Singh, N. P., Bhushan, S., Sharma, M., Sinha, A. K., \& Ahuja, P. S. (2010). Qualitative and quantitative analysis of anthraquinone derivatives in rhizomes of tissue culture-raised Rheum emodi Wall. plants. Journal of Plant Physiology, 167(9), 749-756.

Mallillin, A. C., Trinidad, T. P., Raterta, R., Dagbay, K., \& Loyola, A. S. (2008). Dietary fibre and fermentability characteristics of root crops and legumes. British Journal of Nutrition, 100(3), 485-488.

Manzer, D. S., \& Littlefield, B. A. (1988). Stimulation of IgG production by glucocorticoids in human myeloma lymphoblasts. Biochimica et Biophysica Acta (BBA)-Molecular Cell Research, 969(1), 40-47.

Nesbitt, L. T. (1995). Minimizing complications from systemic glucocorticosteroid use. Dermatologic Clinics, 13(4), 925-939.

Patrono, C., \& Peskar, B. A. (1987). Radioimmunoassay in basic and clinical pharmacology. Springer.

Radhika, R., Krishnakumar, I., \& Sudarsanam, D. (2010). Antidiabetic activity of Rheum emodi in alloxan induced diabetic rats. Int J Pharm Sci Res, 8, 296300 .

Radhika, R., Ragavan, B., Sharad Pawar, D., \& Sudarsanam, D. (2012). Action of marker enzymes of Rheum emodi in alloxan induced diabetic rats. Asian $J$ Exp Biol Sci, 3(2), 420-423. 
Reeves, P. G., Nielsen, F. H., \& Fahey Jr, G. C. (1993). AIN-93 purified diets for laboratory rodents: final report of the American Institute of Nutrition ad hoc writing committee on the reformulation of the AIN-76A rodent diet. Oxford University Press.

Sanghi, D. K., \& Tiwle, R. (2016). Importance of Village Plant Rhubarb. Int J Pharma Res Health Sci, 4(6), 1438-1443.

Seo, E. J., Ngoc, T. M., Lee, S.-M., Kim, Y. S., \& Jung, Y.-S. (2012). Chrysophanol-8-O-glucoside, an anthraquinone derivative in rhubarb, has antiplatelet and anticoagulant activities. Journal of Pharmacological Sciences, 118(2), 245-254.

Shekha, M. S. (2008). The effects of rhubarb root and antihyperlipidemic drug on some physiological parameters in male rats. J Dohuk Univ, 11, 136-143.

Singh, S. S., Pandey, S. C., Singh, R., \& Agarwal, S. K. (2005). 1, 8Dihydroxyanthraquinone derivatives from rhizomes of Rheum emodi Wall.

Syiem, D., Syngai, G., Khup, P. Z., Khongwir, B. S., Kharbuli, B., \& Kayang, H. (2002). Hypoglycemic effects of Potentilla fulgens L. in normal and alloxaninduced diabetic mice. Journal of Ethnopharmacology, 83(1-2), 55-61.

Ullastre, I. S., \& Pérez, A. P. (2011). Hiperglucemia inducida por glucocorticoides. Seminarios de La Fundación Española de Reumatología, 12(3), 83-90.

Wani, S. A., Ashfaq, M., Shah, K. W., \& Singh, D. (2012). Phytochemical screening of methanolic extracts of Podophyllum hexandrum Royle and Rheum emodi Wall. J. Curr. Chem. Pharm. Sc, 2(2), 125-128.

Xing, X., Zhao, Y., Kong, W., Wang, J., Jia, L., Zhang, P., Yan, D., Zhong, Y., Li, R., \& Xiao, X. (2011). Investigation of the "dose-time-response" relationships of rhubarb on carbon tetrachloride-induced liver injury in rats. Journal of Ethnopharmacology, 135(2), 575-581. 


\section{المستخلص العربي}

\section{يحسن الراوند بعض دلالات المناعة وجلوكوز الدم في الجرذان المعرضة}

\section{للجلوكوكورتيكويد}

ينتمي Rheum emodi المعروف باسم الراوند إلى عائلة Polygonaceae ، يستخدم النبات على

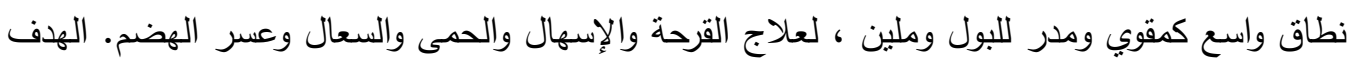

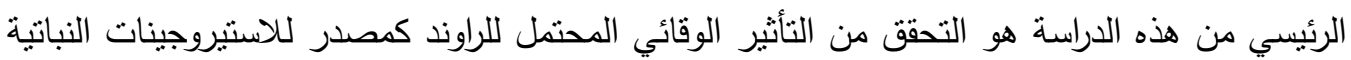

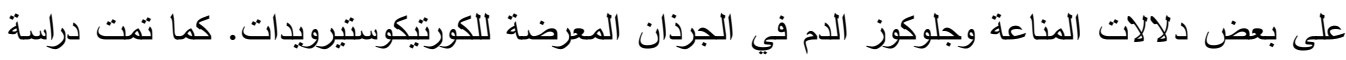
تأثثره في التخفيف من بعض الآثار الجانبية الأخرى للعلاج بالجلوكوكورتيكويد. تم استخدام خمسين

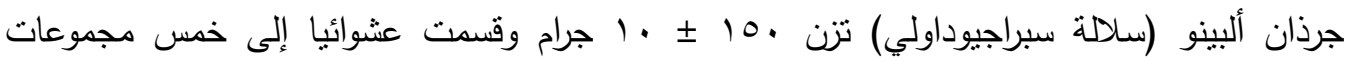

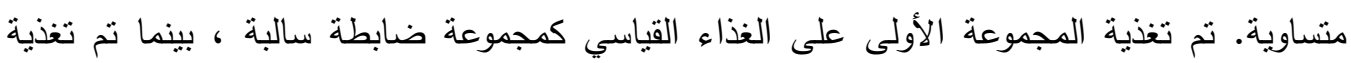
المجموعات الأخرى على الغذاء القياسي المحتوي على . . 1 ملجم من البريدنيزون (كأحد عقاقير

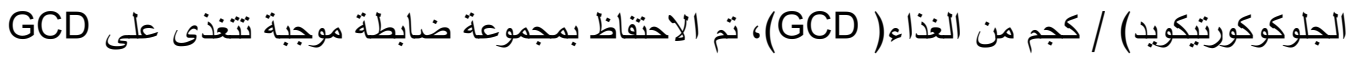

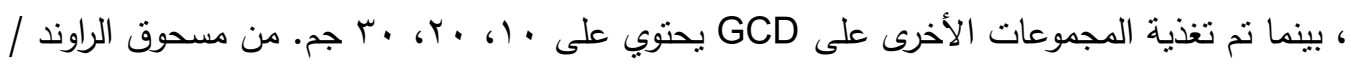

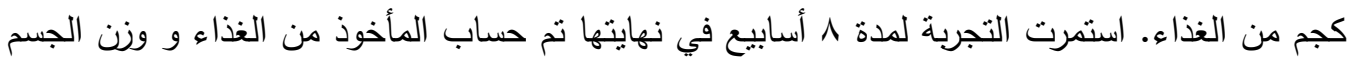

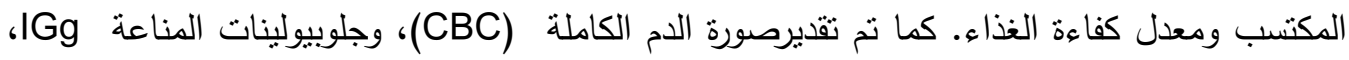

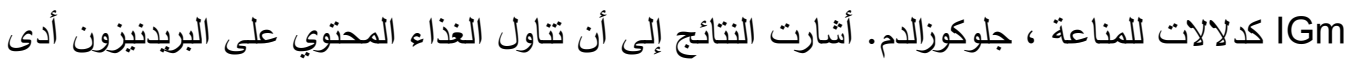

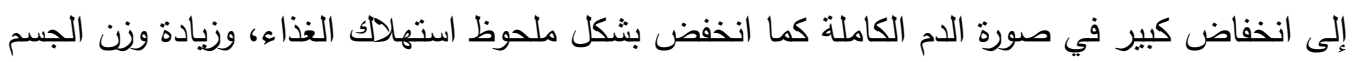
، وبالتالي معدل كفاءة الغذاء في حين ارتفع جلوكوز الدم بشكل ملحوظ. نتج عن تدعيم GCD بالراوند

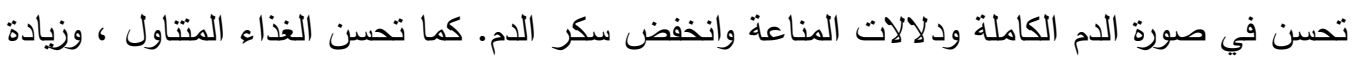

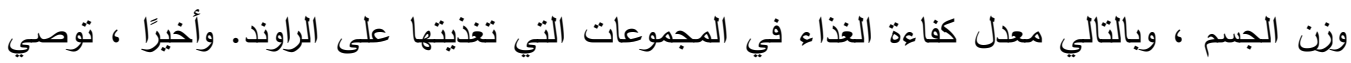

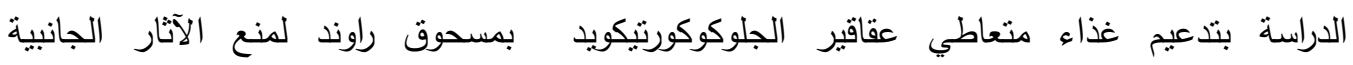

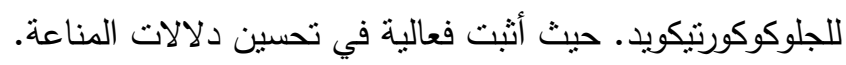
الكلمات المفتاحية: الراوند - الجلوكوكورتيكويد - دلالات المناعة - سكر الدم 